\title{
Evaluation of Suitable Lands for Elaeis guineensis Jacq. Using Geographic Information Systems in the Sierra Region, Tabasco, Mexico
}

\author{
Brindis-Santos, Alfredo I. ${ }^{1}$; Pérez-Roblero, Albina S. ${ }^{1}$; Palma-López, David J. ${ }^{2 *}$; \\ Zavala-Gruz, Joel ${ }^{2}$; Sánchez-Hernández, Rufo ${ }^{3}$; Palma-Cancino David J. ${ }^{4}$ \\ 1 Universidad Autónoma de Chiapas, Facultad de Ciencias Agrícolas, Campus IV, Huehuetán, Chiapas, \\ México, C.P. 30660. \\ 2 Colegio de Postgraduados, Campus Tabasco, Cárdenas, Tabasco, México, C.P. 86500. \\ 3 Unversidad Juárez Autónoma de Tabasco, División Académica de Ciencias Agropecuarias, La Huasteca, \\ Centro, Tabasco, México, C.P. 86280. \\ 4 Universidad Popular de la Chontalpa, Cárdenas, Tabasco, Mexico, C.P. 86556. \\ * Correspondence: dapalma@colpos.mx
}

Citation: Brindis-Santos, A. I., Pérez-Roblero, A. S., Palma-López, D. J., Zavala-Cruz, J., SánchezHernández, R., \& Palma-Cancino D. J. (2021). Evaluation of Suitable Lands for Elaeis guineensis Jacq. Using Geographic Information Systems in the Sierra Region, Tabasco, Mexico. Agro Productividad. https://doi.org/ 10.32854/ agrop.v14i10.2075

Editor in Chief: Dr. Jorge Cadena Iñiguez

Received: May 13, 2021.

Accepted: September 5, 2021.

Published on-line: November 8, 2021

This work is licensed under a Creative Commons Attribution-NonCommercial 4.0 International license.

\section{ABSTRACT}

Objective: The objective of this study was to evaluate the edaphic suitability of Elaeis guineensis at a semidetailed scale (1:50000), in the Plains and Terraces of Tabasco, Mexico (PTT).

Design/Methodology/Approach: The edaphic requirements consisted of a semi-detailed soil map. The evaluation of the edaphic suitability was based on the agroecological zoning methodology proposed by FAO and the final 1:50000 scale map was developed using the algebra mapping tool with the ArcGis ${ }^{\circledR}$ Geographic Information System.

Results: The Gleysols, Fluvisols, Luvisols, and Lixisols groups dominate the PTT, with 65.1, 16.2, 6.3, and $4 \%$, respectively. Most of the soils (79.95\%) have zero suitability for oil palm.

Study Limitations/Implications: Oil palm is the eighth most important perennial crop (over cocoa) for the economy of southeastern Mexico. In this scenario, the expansion of plantations in the country is a possibility; therefore, complying with internal regulations and carry is important.

Findings/Conclusions: The internal drainage of Gleysols soils limits the establishment of E. guineensis plantations in the plains and terraces of Tabasco, Mexico.

Keywords: Oil palm, Precision Agriculture, Gleysols, Lixisols, Luvisols.

\section{INTRODUCTION}

Palm oil is being increasingly used on a large scale, driven by the economic development of countries such as India and China (Murphy, 2014). Palm oil is an enormous world industry with an annual value that exceeds US $\$ 50$ billion (Paterson and Lima, 2017). Most of the crude palm oil is used to produce food and biodiesel, while palm kernel oil is used 
to manufacture detergents, make-up, plastics, and chemical products (Rival, 2017). The large-scale oil palm (E. guineensis Jacq.) cultivation has transformed the tropical regions, the lives of people, and the profits of the palm industry. Its high yield, easy establishment, and low costs make this a very profitable crop (Dislich et al., 2017). For example, oil palm is the eight most important perennial crop in southeastern Mexico, surpassing cacao (SIAP, 2021). However, during the last ten years, the fresh fruit bunches (RFF) yield has not increased in Mexico: it remained at $13 \mathrm{t} \mathrm{ha}^{-1}$ from 2009 to 2019 (SIAP, 2021). On the contrary, the main producing countries in southeastern Asia report $17 \mathrm{t} \mathrm{ha}^{-1} \mathrm{RFF}$ yields (FAO, 2021). In response to the growing domestic demands and to the high cost of palm oil imports - for example, in 2019, Mexico imported 478,900 t of palm oil at a cost of US \$ 265 million (SIAVI, 2021)—, some South American governments are encouraging national and foreign investors to plant more oil palms (FEMEXPALMA, 2020). Therefore, in view of the potential expansion of these plantations in the country, complying with the domestic regulations and carrying out a sustainable crop management is important to increase local production and to reduce oil imports (Brindis-Santos et al., 2020b).

Evaluating suitable lands availability is necessary to establish crops and to obtain an optimal yield; this information is essential for the development of government policies and for investors (Rhebergen et al., 2016). In this regard, Mexico has made efforts to evaluate land suitability for several crops that have an economic importance for the agricultural sector (Aguilar et al., 2013; González and Hernández, 2016; Ramírez-Sánchez et al., 2019). Specific studies about the establishment of forest species (Aguilar-Rodríguez et al., 2017) and perennial crops (Rivera-Hernández et al., 2012), as well as about alternatives for the production of biofuels (González et al., 2015), have been carried out in Tabasco. AcevesNavarro et al. (2008) zoned areas with high production potential for the cultivation of E. guineensis; however, their analysis was carried out more than ten years ago and the evaluation scale (1:250000) was made at reconnaissance level. Consequently, the objective of this research was to carry out a semi-detailed scale (1:50000) evaluation of the edaphic suitability of Elaeis guineensis Jacq., in the plains and terraces of Tabasco (PTT), in order to determine potential areas for this crop.

\section{MATERIAL AND METHODS}

Study Area. The PTT are located at $17^{\circ} 31^{\prime} 57^{\prime \prime}$ and $17^{\circ} 47^{\prime} 44^{\prime \prime} \mathrm{N}$ and $92^{\circ} 42^{\prime}$ $55^{\prime \prime}$ and $92^{\circ} 54^{\prime} 22^{\prime}$ W, in a geographical area of 138,143 ha, located in the Llanura Costera del Golfo Sur geomorphological province, in the municipalities of Jalapa and Tacotalpa, in southeastern Tabasco, Mexico (INEGI, 2016). The study zone has three geomorphological landscapes: active alluvial plains (PFA), detrital coastal terraces (TCD), and soft sloping volcanic hills (LSIV). The prevailing landscape is PFA; it covers $82 \%$ of the total area; it is a flat area located in the lowest topographic position, over fluvial sediments and marshes from the Quaternary period (Holocene). The remaining 18\% of the region consists of terraces and low hills landscapes, over detrital sedimentary rocks and andesite rifts from the Tertiary (Paleocene) and Quaternary (Pleistocene) periods, at an altitude of 7-70 m (Zavala-Cruz et al., 2016). The climates are humid-warm - with abundant rainfall in summer (Am (f)) - and humid-warm — with rainfall all year round 
$(\operatorname{Af}(\mathrm{m}))$. The average temperature is $25^{\circ} \mathrm{C}$ and the annual average precipitation is 2,5004,000 mm (García, 2004).

Elaeis guineensis Suitability Requirements (Climate, Topography, and Soil). Seven edaphic properties of soil were analyzed to determine land suitability: $\mathrm{pH}$, depth, texture, cation exchange capacity $(\mathrm{CIC})$, electric conductivity $(\mathrm{CE})$, base saturation percentage (PSB), and drainage. There are four significant climate and relief variables: temperature, precipitation, height above sea level, and slope. The requirements of the values used to define suitability ranges were based on Ecocrop (2014) and Corley and Tinker (2016); the types of drainage were based on Cuanalo (1990) and Parmananthan (2003). The pH, CIC, GE, and PSB ranges were based on NOM-021-REGNAT (2000) and IUSS Working Group WRB (2015). The lower limits were defined taking into account the information provided by Corley and Tinker (2016), who pointed out that $80 \%$ of the E. guineensis roots can be found at a depth of $0-50 \mathrm{~cm}$.

Edaphic, Climatic, and Relief Data. The soil units' map (1:50000 scale) and the physical and chemical data were obtained from Brindis-Santos et al. (2020a). The precipitation and temperature data were obtained from the cartography of INEGI (2021) (1:250,000 scale); the format was changed from vectors to raster. The relief and slope map was generated based on a LIDAR model, using the $\operatorname{ArcGis}{ }^{\circledR} 9.2$ software (ESRI, 2004).

\section{Zonification of the Elaeis guineensis Edaphic Suitability}

The E. guineensis edaphic suitability was evaluated based on FAO's Agro-Ecological Zoning guidelines (1997). The suitability types were grouped in the following categories: 1) high suitability (i.e., the values of the variables found in the optimal range); 2) medium suitability (which gathers the values of the variables found in the absolute suitability range); and 3) zero suitability (which is defined by the variables whose values are lower than those reported as absolute minimum by Aguilar-Rodríguez et al. (2017)). Using the map algebra tool - which executes all the spatial analysis operators and functions, adding two or more maps to obtain a polygon mix of the original maps' variables (Rivera-Hernández et al., 2012) - , an edaphic suitability map of E. guineensis was generated (1:50000 scale).

\section{RESULTS AND DISCUSSION}

Table 1 shows the variables required to determine the suitability of E. guineensis: soil, climate, and relief.

\section{Physical and Chemical Characteristic of the Soils in the Sierra Region of Tabasco}

Soils from the Gleysols (GL), Fluvisols (FL), Luvisols (LV), and Lixisols (LX) groups prevail in 65.1, 16.2, 6.3, and 4\%, respectively, of the Plains and Terraces of Tabasco (PTT) -which were the subject of this study. GL were formed in zones with reducing conditions; FL, in natural levees and meander banks; and LV and LX, in low hills and terraces. The following representative soil units were found: GL- st.eu- lo.oh (50\%), GL-hi.oy.eu- cen. lop.hu (12.7\%), FL- fve.gl.eu- hu.lo (12.5\%), LV-gl- ct.hu-je.lo.qv (3.6\%), and LX-ab.cr-ct. df.cen.lop.je.pn (3.8\%) (Figure 1). 
Table 1. Elaeis guineensis Jacq. edaphic requirements in Tabasco, Mexico (Ac=clay; $\mathrm{An}=$ sand; $\mathrm{F}=\mathrm{loam} ; \mathrm{L}=$ silt).

\begin{tabular}{|c|c|c|c|c|}
\hline \multirow{2}{*}{ Factor } & \multirow{2}{*}{ Variable } & \multicolumn{3}{|c|}{ Aptitude } \\
\hline & & High & Average & None \\
\hline \multirow{3}{*}{ Weather } & Type: Tropical & $\mathrm{X}$ & $\mathrm{X}$ & \\
\hline & Mean Temperature $\left({ }^{\circ} \mathrm{C}\right)$ & $20-35^{1}$ & $12-20$ y $35-381$ & $<12$ y $>38^{1}$ \\
\hline & Precipitation $(\mathrm{mm})$ & $1500-3000^{1}$ & $1000-1500$ y $3000-80001,2$ & $<1000 \mathrm{y}>80001$ \\
\hline \multirow{7}{*}{ Soil characteristics } & $\mathrm{pH}$ & $4.5-7.51,3$ & $3.2-4.5$ y $7.5-81,3,4$ & $<3.2$ y $>81,3,4$ \\
\hline & Depth $(\mathrm{m})$ & $>1.5^{1}$ & $0.5-1.5^{1}$ & $<0.5^{1}$ \\
\hline & Texture * & $\begin{array}{l}\text { L, LC, LSt, } \\
\text { LCSt } 1,2,3\end{array}$ & LCSd, SdL, SdL, CSd ${ }^{2}$ & $\begin{array}{c}\mathrm{Sd}, \mathrm{C}, \mathrm{St} \text {, gravel } \\
1,2,3\end{array}$ \\
\hline & Cation-exchange capacity $\left(\mathrm{Cmol}(+)\left(\mathrm{kg}^{-1}\right)\right.$ & $>24$ & $14-24^{7}$ & $<14$ \\
\hline & Salinity by electric conductivity $\left(\mathrm{dS} / \mathrm{m}^{-1}\right)$ & $<4^{1}$ & $<4^{1}$ & $>4^{12}$ \\
\hline & Exchangeable bases, \% & $>50$ & $20-50$ & $<20$ \\
\hline & Drainage & $\begin{array}{c}\text { Good to average } \\
1,2\end{array}$ & $\begin{array}{c}\text { Good to excesive, poor, slow, } \\
\text { easy to drain } 1,2,4\end{array}$ & Poor, hard to drain ${ }^{4}$ \\
\hline \multirow{2}{*}{ Topographical relief } & Altitude (meters above sea level) & $0-500^{5}$ & $500-1300^{1}$ & $>1300$ \\
\hline & Slope & $<122,4$ & $12-232,4$ & $>23^{4}$ \\
\hline
\end{tabular}

GL and FL have slow permeability (in horizon A) and very slow permeability (in underlying horizons $\mathrm{C}$ ); they have loamy and loamy clayey textures (FL) and clayey texture (GL). Their $\mathrm{pH}$ ranges from moderately acid to neutral. A and C horizons have contrasting organic matter $(\mathrm{OM})$ contents (rich to very poor); nutrients range from high to low (both with assimilated $\mathrm{P}$ and $\mathrm{CIC}$ ), with over $50 \%$ with PSB. These highly-fertile soils are suitable for intensive agriculture; however, water excess causes anaerobiosis and oxide-reduction processes in these soils (Palma-López et al., 2017; Brindis-Santos et al., 2020a) (Figure 1). LV and LX share the following characteristics: loamy clay, silty clay, and clayey texture; Bt horizon formed through the accumulation of clay; good to imperfect drainage; rich to poor organic matter content; high to low nutrients with P; cation exchange capacity (CIC); base saturation percentage (PSB); and moderately to strongly acid $\mathrm{pH}$. These conditions limit agricultural capacity (Zavala-Cruz et al., 2016).

Climatic and Relief Characteristics of Tabasco's Sierra Region. Am(f) climate prevails in the center, north, and northeast; while Af(m) prevails in the South and Southeast of the PTT; the average temperature is $25^{\circ} \mathrm{C}$. Fifty-seven percent of the area is suitable for E. guineensis, as a result of the average (2000-3000 mm) and moderate (43\%; 3000-4000 $\mathrm{mm}$ ) annual precipitation in southern Tacotalpa. These findings match those reported by Paramananthan (2003), who argues that E. guineensis grows better with a 2000-2500 mm year ${ }^{-1}$ precipitation, evenly distributed throughout the year (no month with $<100$ $\mathrm{mm}$ of rain). Relief and slope intervals have the following characteristics: a) flat to gentle, $0-12 \%$ (97\% of the PTT); b) moderate to steep, 12-24\% (2.5\% of the PTT), to the South and Northeast; and c) very steep, $>25 \%(0.07 \%$ of the PTT), to the Southwest. Altitude ranges from 7 to 70 masl (Figure 2). 


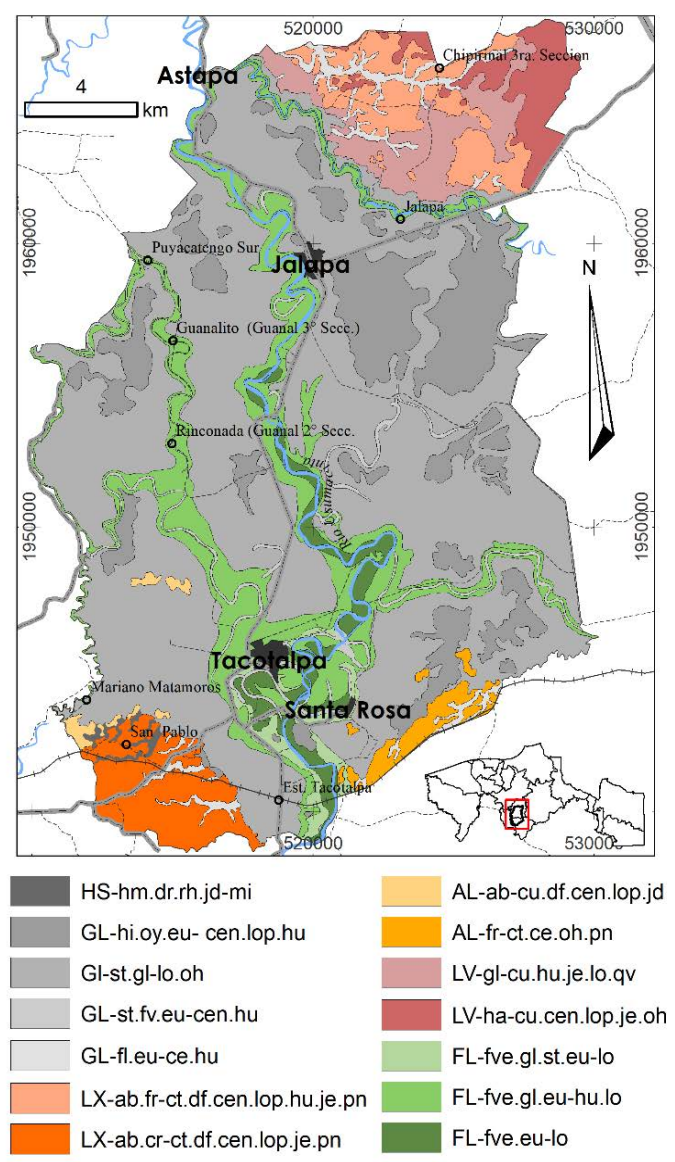

Figure 1. Soil survey in La Sierra, Tabasco, Mexico (Brindis-Santos et al., 2020a). meaning of abbreviations: GL-st.fl.eu-ce.hu/ Eutric Fluvic Stagnic Gleysol (Clayic, Humic), FL.fve.gl.st.eu-lo/ Eutric Stagnic Gleyic Pantofluvic Fluvisol (Loamic), FL-fve.gl.eu-hu.lo/ Eutric Gleyic Pantofluvic Fluvisol (Humic, Loamic), FLfve.eu-lo/ Eutric Pantofluvic Fluvisol (Loamic), GL-st.eu-lo.oh/Eutric Stagnic Gleysol (Loamic, Ochric), GLhi.oy.eu-cen.lop.hu/ Eutric Oxigleyic Histic Gleysol (Endoclayic, Epiloamic, Humic), GL-fv.eu-ce.hu/Eutric Fluvic Gleysol (Clayic, Humic) LV-gl-ct.hu.je.lo.qv/ Gleyic Luvisol (Cutanic, Humic, Hypereutric, Loamic, Protovertic), LX-ab.fr-ct.df.cen.lop.hu.je.pn/ Ferric Abruptic Lixisol (Cutanic, Differentic, Endoclayic, Epiloamic, Humic, Hypereutric, Profondic) AL-fe-ct.ce.oh.pn/ Ferric Alisol (Cutanic, Clayic, Ochric, Profondic), LV-ha-cu.cen.lop.je.oh/ Haplic Luvisol (Cutanic, Endoclayic, Epiloamic, Hipereutric, Ochric), HS-hm.dr.rh.jd-mi/Hyperdystric Rheic Drainic Hemic Histosol (Mineralic), LX-ap.cr-ct.df.cen.lop.je.pn/ Chromic Abruptic Lixisol (Cutanic, Differentic, Endoclayic, Epiloamic, Hipereutric, Profondic), AL-ab-cu. df.cen.lop.jd/ Abruptic Alisol (Cutanic, Differentic, Endoclayic, Epiloamic, Hyperdistric).

Edaphic suitability for Elaeis guineensis in the Sierra Region of Tabasco. The PTT has 1532.26 ha that are ideal for oil palms (3.75\% of the total surface area). Lands with at least one limiting condition comprised 7875.09 ha (19.29\%). It has been determined that this area is non-suitable for the production of E. guineensis, as a result of its CIC, interchangeable bases, drainage, and topography. This area comprises 31414.50 ha. The FL-fve.eu.lo unit has high suitability for E. guineensis (Figure 3): it has a deep soil (>100 $\mathrm{cm})$; its surface layer $(0-50 \mathrm{~cm})$ has loamy, silty loam, and clayey loamy silt textures; it has a good internal drainage at a depth of $100 \mathrm{~cm}$; it does not have salinity problems; and it has over 50\% PSB. 

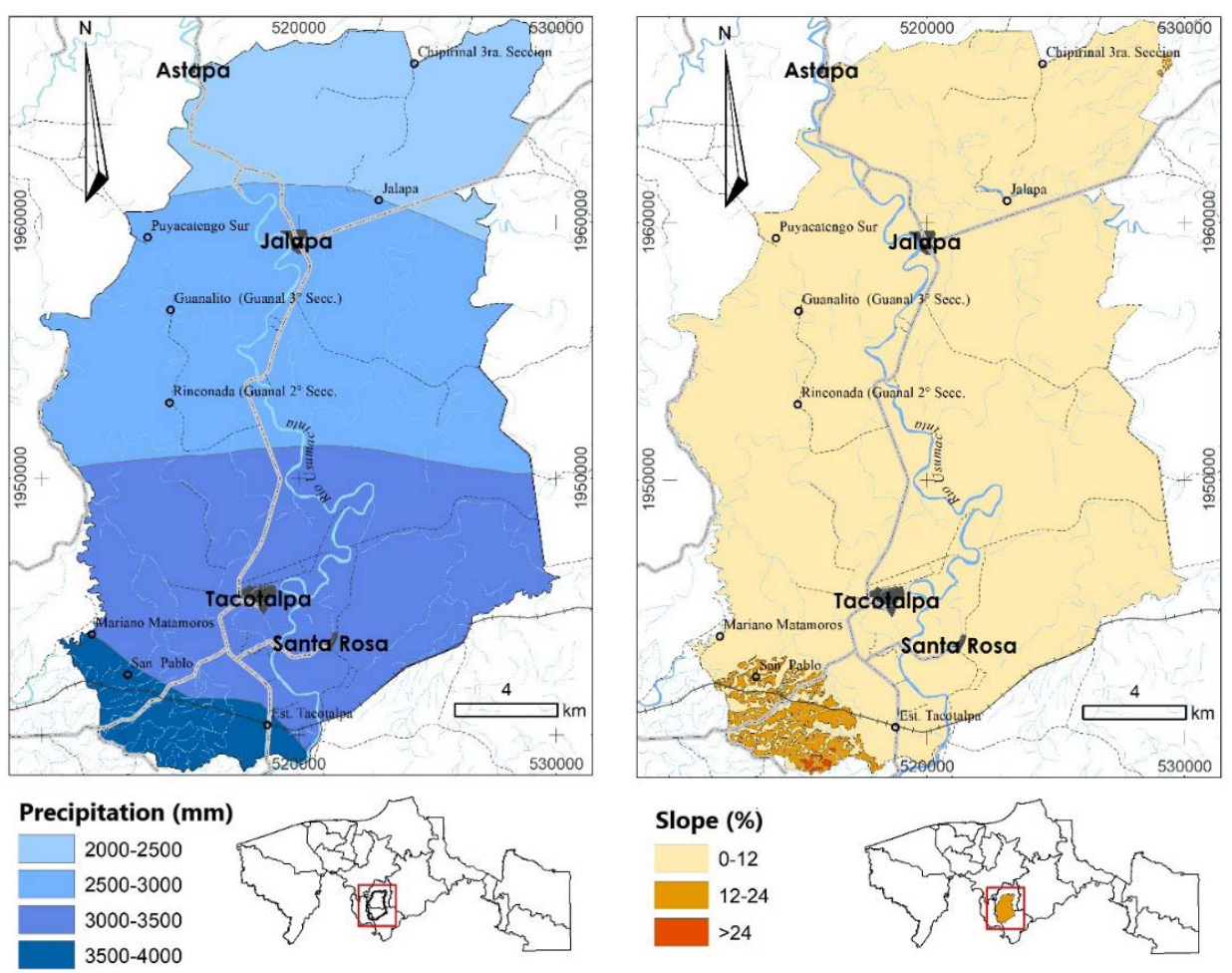

Figure 2. Precipitation and topography in La Sierra, Tabasco, Mexico.

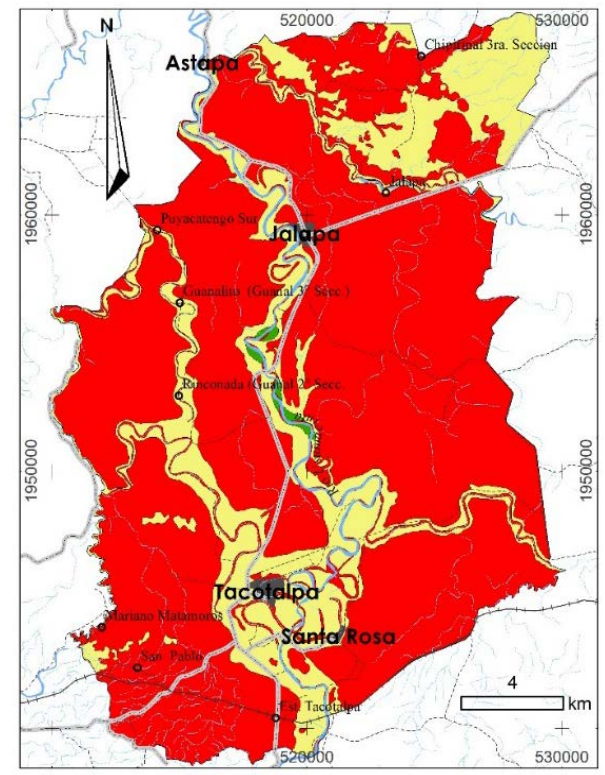

Soil aptitude Elaeis guineensis
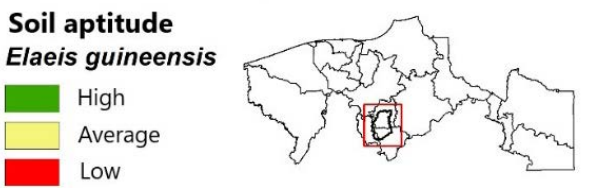

Figure 3. Soil aptitude for Elaeis guineensis in La Sierra región, Tabasco, Mexico. 
These properties match those of other soils suitable for E. guineensis in other tropical regions (Paramananthan, 2003; Corley and Tinker, 2016). Meanwhile, Rhebergen et al. (2016) maintain that the soil's physical properties — which control the soil's capacity to provide water for the crops - are more important than its chemical properties - which cannot be easily changed through handling. The soils in the study area have variables with optimum values to expand the surface in which the crop is grown. Low fertility is the edaphic variable that causes an average suitability for E. guineesis in the PTT's Lixisols (except in Luvisols with poor drainage). Nutrient availability is not a major limiting factor for the evaluation of land suitability, since handling can be carried out adding nutrients and returning residues to the soil. However, correcting the poor to slow drainage that limits this perennial crop is a difficult task (Rhebergen et al., 2016; Harahap et al., 2018).

Gleysols (GL) with various qualifiers dominate relieves with low topographical position. This zone shows reducing conditions, a gley color pattern, and a 7-150 cm depth, as a result of the high-water table and the water stagnation associated with medium and fine textures (Brindis-Santos et al., 2020a).

GLs with zero suitability for E. guineensis cover most of the study area surface $(76.95 \%$ of the PTT); these soils show slow permeability in horizon A (which is associated with a clayey texture) and moderate permeability in underlying $\mathrm{Cg}$ horizons (as a result of the decrease in the clay content). The area has stagnic properties, as a consequence of its high-water table. These soil color reducing conditions can be found on the first $50 \mathrm{~cm}$ of depth - as seen in the dominance of grey and deep grey colors. According to their geographical position, these characteristics are divided into decantation basins, floodplains, and cumulative valleys (Zavala-Cruz et al., 2016). However, this unfavorable physical soil conditions limit root growth and function - leading to plants with inadequate growth (Ogunkunle, 1993) - and, even when fertilizers are applied, they reduce nutrient and water absorption -inhibiting microbial growth (Goh et al., 2016).

\section{CONGLUSION}

The poor internal drainage of Gleysols in most of the plains and terraces of Tabasco, Mexico, limits the establishment of E. guineensis in those areas. Land suitability in the study area is ideal (3.75\%), medium (19.29\%), and zero (76.95\%). Climatic suitability ranges from medium-high to medium as a result of the relief (<70-masl heights and $30 \%$ slopes).

\section{REFERENGES}

Aceves, N.L.A., Juárez, L.J.F., Palma-López, D.J., López, L.R., Rivera, H.B., Rincón, R.J., Morales, C.A.R. (2008). Estudio para determinar zona de alta potencialidad del cultivo de palma de aceite (Elaeis guineensis Jacq) en el estado de Tabasco. Colegio de Postgraduados, Gobierno del Estado de Tabasco, Villahermosa, México. 38 p.

Aguilar Rivera, N., Olvera Vargas, L. A., Galindo Mendoza, G. (2013). Evaluación de aptitud de tierras al cultivo de caña de azúcar en la Huasteca potosina, México, por técnicas geomáticas. Revista de Geografía Norte Grande 55. 141-156. Doi:10.4067/S0718-34022013000200010

Aguilar-Rodríguez, J.R., Zavala-Cruz, J., Juárez-López, F., Palma-López, D.J., Castillo-Acosta, O., ShirmaTorres, E. (2017). Aptitud edáfica de Eucalyptus urophylla ST Blake en la terraza de Huimanguillo, Tabasco, México. Agroproductividad 10, (12). 79-85.

Brindis-Santos, A.I., Palma-López, D.J., Zavala-Cruz, J., Mata-Zayas, E.E., López-Bustamante, Y.I. (2020). Paisajes geomorfológicos relacionados con la clasificación de los suelos en planicies y 
terrazas de Tabasco, México. Boletín de la Sociedad Geológica Mexicana. 72, (1). 1-17. Doi: 10.18268/ BSGM2020v72nla090919.

Brindis-Santos, A.I., Sánchez-Hernández, R., Mata-Zayas, E.E., Palma-López, D. J., Sánchez-Gutiérrez, F., del Carmen Cámara-Cabrales, L. (2020). Almacenamiento de carbono en la biomasa aérea de agrosistemas tropicales en Tabasco, México. Ecosistemas y Recursos Agropecuarios 7(3). 1-13.

Corley, R.H.V., Tinker, P.B. (2016). The oil palm. 5th Edition. Wiley Blackwell. UK. 639p.

Guanalo de la C. H. (1990). Manual para la descripción de perfiles de suelos en el campo. Colegio de Postgraduados. Chapingo, México. 40 p.

Dislich, G., Keyel, A.C., Salecker, J., Kisel, Y., Meyer, K.M., Auliya, M., Wiegand, K. (2017). A review of the ecosystem functions in oil palm plantations, using forests as a reference system. Biological Reviews of the Cambridge Philosophical Society 49: 1539-1569. doi: 10.1111/brv.12295

ECOCROP (2014), The adaptability level of the FAO crop environmental requirements database. Food and Agriculture Organization of the United Nations. Versión 1.0. Agls. Rome, Italy.

ESRI. 2004. ArcGIS 9 what is ArcGis? Redland, USA. 119 p.

FAO. (1997). Zonificación agroecológica guía general. Boletín de Suelos de la FAO, Núm. 73. Organización de las Naciones Unidas para la Agricultura y la Alimentación, Roma, Italia. 96 p.

FAO. (2021). Food and Agriculture Organization of the United Nations. FAOSTAT Database. Disponible en: http://www.fao.org/faostat/es/\#data

FEMEXPALMA. (2020). Federación Mexicana de Palmicultores y Extractores de Palma de Aceite A.C. Anuario Estadístico 2020. Villahermosa, Tabasco: S/E.

García, E. (2004). Modificación al sistema de clasificación climática de Köppen. Instituto de Geografía. UNAM, Distrito Federal, México 91 p.

Goh, K.J., Mahamooth, T.N., Ng, H.P., Teo, C.B., Liew, Y.A. (2016). Managing Soil Environment and Its Major Impact on Oil Palm Nutrition And Productivity In Malaysia.

González, M.R.,Juárez, L.J.F., Aceves, N.L.A., Rivera, H.B., Guerrero, P.A. (2015). Zonificación edafoclimática para el cultivo de Jatropha curcas L., en Tabasco, México. Investigaciones Geográficas. 86. 25-37.

González, H.A.G., Santana, J.R.H. (2016). Zonificación agroecológica del Coffea arabica en el municipio Atoyac de Álvarez, Guerrero, México. Investigaciones Geográficas. 90: 105-118. Doi: doi.org/10.14350/ rig.49329

INEGI. (2016). Instituto Nacional de Estadística y Geografía Anuario estadístico y geográfico de Tabasco, 2016: México, Instituto Nacional de Estadística y Geografía. INEGI 461 p.

Murphy, D.J. (2014). The future of oil palm as a major global crop: Opportunities and challenges. Journal of Oil Palm Research. 26, (1).1-24.

NOM-021-RECNAT, (2000). Establece las especificaciones de fertilidad, salinidad y clasificación de suelos, estudio, muestreo y análisis. Diario oficial de la federación: México, Semarnat 85 p.

Ogunkunle, A.O. (1993). Soil in land suitability evaluation: an example with oil palm in Nigeria. Soil use and management. 9(1): 35-39. Doi: 10.1111/j.1475-2743.1993.tb00925.x

Palma-López, D., Zavala-Cruz, J., Bautista-Zuñiga, F., Morales-Garduza, M., López-Castañeda, A., ShirmaTorres, E., Tinal-Ortiz, S. (2017). Clasificación y cartografía de suelos del estado de Campeche, México. Agroproductividad 10(12): 71-78.

Paramananthan, S. (2003). Land Selection for Oil Palm. En: Härdter, R., Fairhurst, T.H.(Eds.), Oil Palm Managament for Large and Sustainable Yields. Potash \& Phosphate Institute/Potash \& Phosphate Institute of Canada (PPI/PPIC) andInternational Potash Institute (IPI), Singapore, pp. 27-58.

Paterson, R.R.M., Lima, N. (2018). Climate change affecting oil palm agronomy, and oil palm cultivation increasing climate change, require amelioration. Ecology and evolution. 8(1). 452-461. Doi:10.1002/ ece3.3610

Ramírez-Sánchez, L.G., Morales-Manilla, L.M., Vilchis-Mata, I., Trujillo-Herrada, A., Castelo-Agüero, D.D.C. (2019). Evaluación territorial para el cultivo del aguacate (Persea americana Mill. cv. Hass) en la región del pico de Tancítaro, Michoacán, México. Agrociencia 53(4): 487-503.

Rival, A. (2017). Breeding the oil palm (Elaeis guineensis Jacq.) for climate change. Oilseeds \& Fats Crops and Lipids. 24(1).107. doi: 10.1051/ocl/2017001

Rivera-Hernández, B., Aceves-Navarro, L.A., Juárez-López, J., Palma-López, D.J., González-Mancillas, R., González-Jiménez, V. (2012). Zonificación agroecológica y estimación del rendimiento potencial del cultivo de la yuca (Manihot esculenta Crantz) en el estado de Tabasco, México. Avances en investigación agropecuaria 16(1). 29-47.

Rhebergen, T., Fairhurst, T., Zingore, S., Fisher, M., Oberthür, T., Whitbread, A. (2016). Climate, soil and land-use based land suitability evaluation for oil palm production in Ghana. European Journal of Agronomy. 81. 1-14. doi: 10.1016/j.eja.2016.08.004 
SIAP. (2021). Servicio de Información Agroalimentaria y Pesquera. Cierre de la producción agrícola por cultivo 2019. Avance de siembras y cosechas por cultivo Consultado: 26 de marzo 2021. Disponible en: https://www.gob.mx/siap/acciones-y-programas/produccion-agricola-33119

SIAVI. (2021). Sistema de Información Arancelaria Vía Internet. Obtenido de Importaciones e Importaciones Consultado: 26 de marzo 2021. Disponible en: http://www.economia-snci.gob.mx/

Zavala-Cruz, J., Jiménez-Ramírez, R., Palma- López, D.J., Bautista-Zuñiga, F., Gavi-Reyes, F. (2016). Paisajes geomorfológicos: base para el levantamiento de suelos en Tabasco, México. Ecosistemas y Recursos Agropecuarios. 3: 161-171.

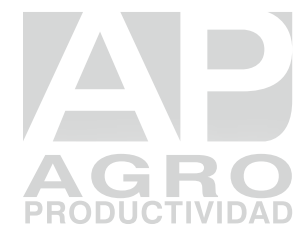

